\title{
Detection, Distribution and Health Risk Assessment of Toxic Heavy Metals/Metalloids, Arsenic, Cadmium, and Lead in Goat Carcasses Processed for Human Consumption in South-Eastern Nigeria
}

\author{
Emmanuel O. Njoga ${ }^{1, *(D)}$, Ekene V. Ezenduka ${ }^{1}\left(\mathbb{D}\right.$, Chiazor G. Ogbodo $^{1}$, Chukwuka U. Ogbonna $^{2}{ }^{(D)}$, \\ Ishmael F. Jaja ${ }^{3}$, Anthony C. Ofomatah ${ }^{4}$ and Charles Odilichukwu R. Okpala ${ }^{5, *(D)}$ \\ 1 Department of Veterinary Public Health and Preventive Medicine, Faculty of Veterinary Medicine, \\ University of Nigeria, Nsukka 410001, Nigeria; ekene.ezenduka@unn.edu.ng (E.V.E.); \\ kiaradollz21@gmail.com (C.G.O.) \\ 2 Department of Biochemistry, Federal University of Agriculture Abeokuta, Ogun State 110124, Nigeria; \\ ogbonnacu@funaab.edu.ng \\ 3 Department of Livestock and Pasture Science, University of Fort Hare, Alice 5700, South Africa; \\ ijaja@ufh.ac.za \\ 4 National Centre for Energy Research and Development, University of Nigeria, Nsukka 410001, Nigeria; \\ ofomatony@yahoo.co.uk \\ check for \\ updates \\ Citation: Njoga, E.O.; Ezenduka, \\ 5 Department of Functional Food Products Development, Faculty of Biotechnology and Food Science, \\ Wrocław University of Environmental and Life Sciences, 51-630 Wrocław, Poland \\ * Correspondence: njoga.emmanuel@unn.edu.ng (E.O.N.); charlesokpala@gmail.com (C.O.R.O.)
} E.V.; Ogbodo, C.G.; Ogbonna, C.U.; Jaja, I.F.; Ofomatah, A.C.; Okpala, C.O.R. Detection, Distribution and Health Risk Assessment of Toxic Heavy Metals/Metalloids, Arsenic, Cadmium, and Lead in Goat Carcasses Processed for Human Consumption in South-Eastern Nigeria. Foods 2021, 10, 798. https:// doi.org/10.3390/foods10040798

Academic Editor: Ángel José Gutiérrez Fernández

Received: 6 March 2021

Accepted: 6 April 2021

Published: 8 April 202

Publisher's Note: MDPI stays neutral with regard to jurisdictional claims in published maps and institutional affiliations.

Copyright: () 2021 by the authors. Licensee MDPI, Basel, Switzerland. This article is an open access article distributed under the terms and conditions of the Creative Commons Attribution (CC BY) license (https:// creativecommons.org/licenses/by/ $4.0 /)$.

Abstract: Notwithstanding the increased toxic heavy metals/metalloids (THMs) accumulation in (edible) organs owed to goat's feeding habit and anthropogenic activities, the chevon remains increasingly relished as a special delicacy in Nigeria. Specific to the South-Eastern region, however, there is paucity of relevant data regarding the prevalence of THMs in goat carcasses processed for human consumption. This work was, therefore, aimed to investigate the detection, distribution and health risk assessment of THMs in goat carcass processed for human consumption in South-Eastern Nigeria. To achieve this, a total of 450 meat samples (kidney, liver and muscle) were evaluated from 150 randomly selected goat carcasses processed in two major slaughterhouses in Enugu State. The detection, distribution, as well as health risk assessment parameters followed standard procedures. Results revealed that at least one THM was detected in $56 \%$ of the carcasses. Mean concentrations of arsenic (As) were $0.53 \pm 0.10 \mathrm{mg} / \mathrm{kg}, 0.57 \pm 0.09 \mathrm{mg} / \mathrm{kg}$ and $0.45 \pm 0.08 \mathrm{mg} / \mathrm{kg}$, lead $(\mathrm{Pb})$ were $0.48 \pm 0.38 \mathrm{mg} / \mathrm{kg}, 0.45 \pm 0.24 \mathrm{mg} / \mathrm{kg}$ and $0.82 \pm 0.39 \mathrm{mg} / \mathrm{kg}$, cadmium $(\mathrm{Cd})$ was $0.06 \pm 0.32 \mathrm{mg} / \mathrm{kg}$, $0.02 \pm 0.00 \mathrm{mg} / \mathrm{kg}$, and $0.02 \pm 0.00 \mathrm{mg} / \mathrm{kg}$ for kidney, liver and muscle tissues, respectively. The estimated daily intakes (EDI) for all THMs were above the recommended safe limits. The target hazard quotient (THQ) and hazard index (HI) computed for all As, Cd and Pb fell below unity in all the studied organs, which indicated no non-carcinogenic risks. Curtailing the anthropogenic activities that aid the THM-contamination in goat production/processing lines is recommended. Screening for THM-contamination in Nigerian slaughterhouses is imperative, so as to ascertain the toxicological safety of meats intended for human consumption.

Keywords: arsenic (As); cadmium $(\mathrm{Cd})$; lead $(\mathrm{Pb})$; consumer food safety; goat meat; health risk; toxic heavy metals

\section{Introduction}

Heavy metals/metalloids (HMs) entail chemical elements with a density greater than $5 \mathrm{~g} / \mathrm{cm}^{3}$ or specific gravity of at least five times greater than that of water [1]. Required in minute quantities for homeostasis and optimal body function, excess or prolonged intake of 
such micronutrients like $\mathrm{Zn}, \mathrm{Fe}, \mathrm{Cu}, \mathrm{Mn}, \mathrm{Co}, \mathrm{Mo}$, and $\mathrm{Cr}$ may result in adverse health conditions [2]. Toxic heavy metals/metalloids (THMs) refer to relatively dense metals/metalloids not actually beneficial in both humans and livestock, which in small amounts can lead to carcinogenicity, organ toxicity and other deleterious health effects [1,3-9]. Examples like arsenic (As), cadmium $(\mathrm{Cd})$, lead $(\mathrm{Pb})$ and mercury $(\mathrm{Hg})$ are among the top ten THMs of major public health concern by the World Health Organization (WHO) of the United Nations [10]. The toxicity of THMs has always been dependent on the dose, route of exposure, age and nutritional statuses of the exposed individuals or animals [11,12]. Multiple industrial, domestic, agricultural, medical and technological uses of THMs may result in heavy environment pollution with the toxic metals and the possibilities of food-producing animals (FPAs) and humans getting exposed [13]. HM-contaminated pasturelands and water outlets, and indiscriminate use of acaricides, are among THMs entry pathways in edible tissues of FPAs $[14,15]$ for onward transmission to humans via the food chain. Notwithstanding that THMs may naturally occur in minute quantities in the environment, certain anthropogenic activities can exacerbate the pollution of pastureland or water outlets used for food-animal production, especially with toxic metals [16,17].

In Nigeria, the environmental contamination with THMs could increase given anthropogenic activities like: (a) the indiscriminate (agricultural) use of agrochemical; (b) unregulated artisanal mining; (c) crude oil spillage due to oil pipeline vandalism; (d) natural gas flaring; (e) excessive use of explosives (bombs and other improvised explosive devices) associated with crisis like insurgency and or terrorism; and (d) improper disposal of industrial effluents. Environmental contamination with THMs undoubtedly affects pastures, fodder plants, or drinking water sources [16] used for livestock production where the soil serves as platform for either phytoremediation or active uptake [18,19]. A schematic diagram depicting the complexities associated with $\mathrm{As}, \mathrm{Cd}$ and $\mathrm{Pb}$ as THMs, from pathogenesis to progression of certain disease conditions, is shown in Figure 1. Indeed, these THMs can bring about a number of adverse health effects, and in diverse ways. The onset and type of clinical manifestations associated with THMs-toxicity depend on the type of metal involved and the affected organ. Unstable chemically, THMs are able to bind with the biomolecules (proteins, enzymes, phospholipids, hormones and other tissue constituents) to form other chemical complexes [20,21]. Such (THMs-biomolecule) complexes may result in either irreversible or detrimental alterations in its biochemistry, transport, neurotransmission or signaling systems particularly within the affected host [1,20-22]. Further, the THMs can interact with the cellular components, for instance, DNA and nuclear proteins, and bring about conformational changes, which could appear in a form of carcinogenesis or detrimental cell cycle modulation [23-25]. Additionally, an organ failure or malfunction could arise. This is because THMs in both bound and unbound forms could accumulate in vital organs, like kidney, brain, and liver $[13,26]$. Whether in the environment, or in the animal/human tissue, the THMs remain among crucial chemical pollutants, given its bio-accumulation/magnification potentials occasioned by diminutive (tissue) biodegradability [27]. Excessive amounts of THMs in edible tissues of food animals would either directly indicate the degree of meat's toxicological safety, or indirectly indicate the environmental contamination or pollution of toxic metals. Given their voracious appetite and low-grazing feeding habit, goats (Capra hircus) are particularly prone to ingestion of THMs during grazing [28]. The peculiar feeding habits of goat may facilitate geophagia, which increases its propensity to ingest THMs deposited on the soil surface, especially if grazing a contaminated pastureland. 


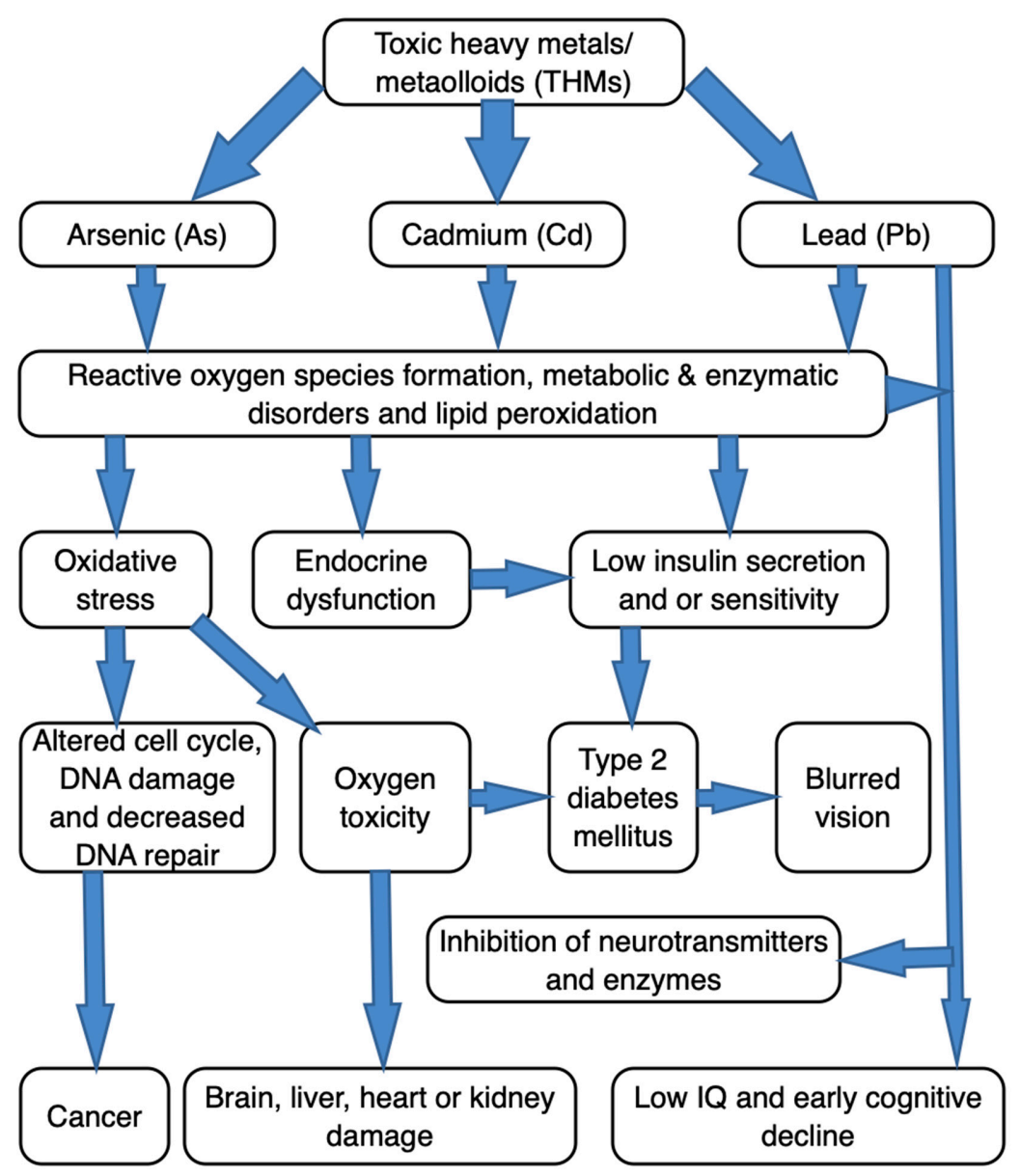

Figure 1. A schematic diagram depicting the complexities associated with toxic heavy metals (also 'metalloids'), arsenic, cadmium and lead, in the pathogenesis and progression of certain disease conditions of public health importance.

Given the food safety concerns associated with accumulated THMs, international food safety regulatory authorities like those under the European Commission [29] have set maximum permissible limits (MPL) for the metals in edible animal products. It is illegal for THMs to occur in edible tissues above the stipulated MPL given the substantial health risks and adverse health effects its exposures pose to human. Typical example includes "itia-itia" (it hurts, it hurts) disease first reported in Toyama Prefecture, Japan, around 1912, owed to the mass $\mathrm{Cd}$ poisoning, characterized by osteomalaecia with excruciating joint and spine pains and kidney dysfunction. Additionally, the ingestion of THMs in food or water can result in organ dysfunction and carcinogenicity [1,30-32]. With about 74 million goats as of 2016, Nigeria is the highest producer of goat in Africa, the third largest producer globally, and the second largest chevon consumer (in Africa) [33,34]. Meat offals like kidneys and liver are edible and increasingly preferred across several communities in Africa [35]. Since THMs bio-accumulate in these organs (that is, kidneys and liver) [17,36], an active surveillance is warranted to safeguard public health. Notwithstanding, the increased THMs accumulation in (edible) organs owed to goat's feeding habit and anthropogenic activities, the chevon remains increasingly relished as a special delicacy in Nigeria. Thus, the indiscriminate anthropogenic activities that result in environmental contamination, and subsequent accumulation of THMs $[37,38]$ makes the detection and quantification of toxic metals in goat carcasses processed for human consumption in Nigeria imperative. The work by Okoye and Ugwu [39], to our best knowledge, appears to be the only recent report on toxic metal contamination of goat muscles and edible offals, which was specific to the South-Eastern region of Nigeria, and this was conducted over a decade ago. 
Despite that contamination of natural water bodies/pasturelands used for goat production continues to persist, the demand as well as consumption specific to goat carcass in various region of Nigeria continues to increase [40]. Previous studies largely in Northern region of Nigeria, on THM contamination in FPAs like cattle, camel, goat and sheep slaughtered for human consumption have been reported [32,41-43]. Specific to the South-Eastern region however, there is paucity of relevant data regarding the prevalence of THMs in goat carcasses processed for human consumption. This paucity of relevant data may be contributing to the impediment on establishment as well as implementation of food safety regulations regarding (THMs) contamination in goat carcasses, especially with respect to chevon. Besides, in most Nigerian slaughterhouses, unfortunately, the screening for THMs in meats appears not standardly conducted during the routine meat inspection processes, and this needs to change. To supplement existing information, therefore, this work was aimed to investigate the detection, distribution and health risk assessment of THMs in goat carcass processed for human consumption in Enugu State, which is in South-Eastern Nigeria. The target is to see if we can acquire a better understanding about the current status of goat carcass contamination with THMs, as well as some additional insights about its toxicological safety, specific to the South-Eastern Nigeria.

\section{Materials and Methods}

\subsection{Schematic Overview of Experimental Program}

The schematic overview of the experimental program, from design of study, study location and sample collection, its preparation, digestion, and THM determinations, identification of operational parameters, to the health risk assessment, are depicted in Figure 2. For emphasis, this current work has been designed to understand the extent THMs would be detected in goat carcasses, how it is distributed and the extent of health risks they may pose to human consumption specific to Enugu State, South-Eastern part of Nigeria. All the steps followed to carry out the entire analytical procedures in this study were consistent with published references. The end target was to understand better the status of goat carcass contamination with respect to the THMs, and if possible provide some insights about its toxicological safety.

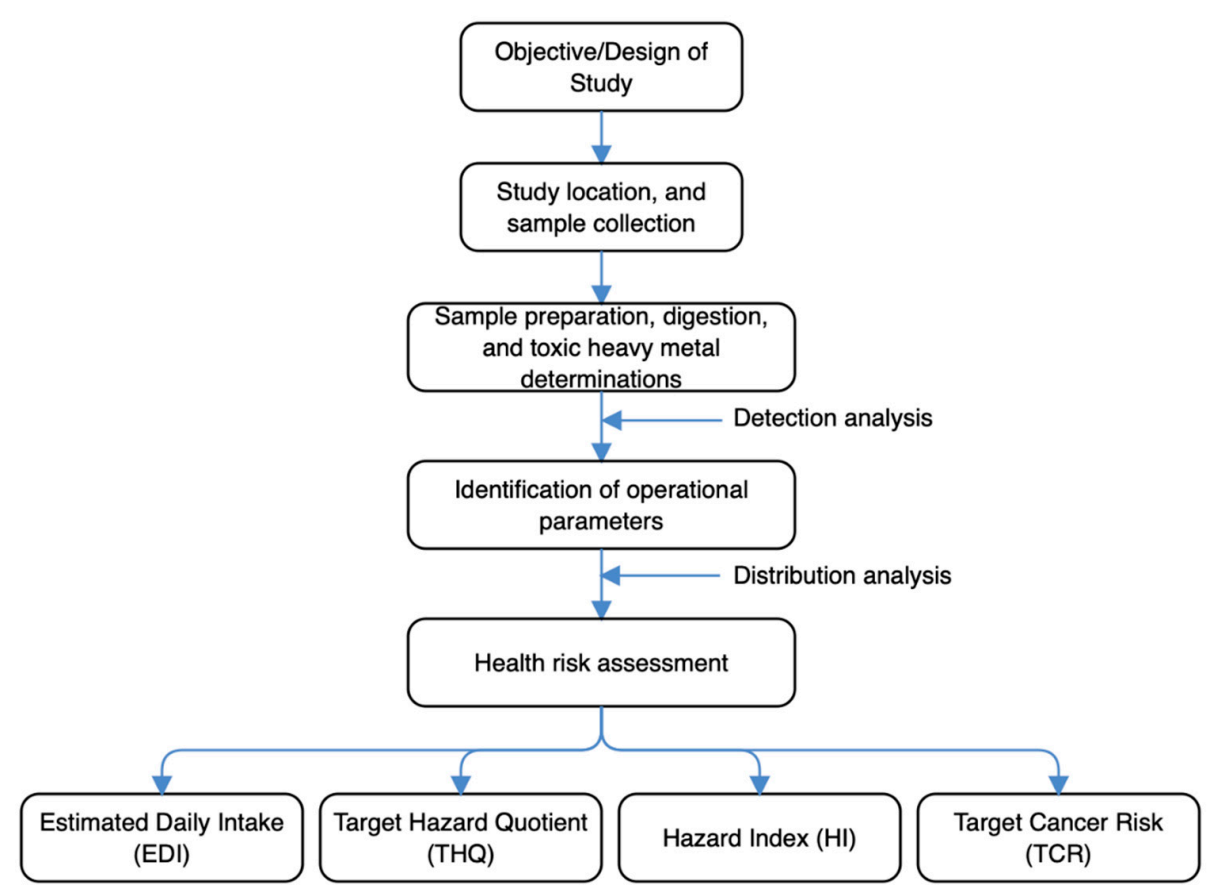

Figure 2. The schematic overview of the experimental program, from design of study, study location and sample collection, its preparation, digestion, and toxic heavy metals/metalloids (THMs) determinations, identification of operational parameters, to the health risk assessment. 


\subsection{Study Location and Sample Collection}

The study location was Enugu State $\left(6^{\circ} 51^{\prime} 24^{\prime \prime} \mathrm{N}\right.$ and $\left.7^{\circ} 23^{\prime} 45^{\prime \prime} \mathrm{E}\right)$, situated in the Southeast geo-political zone of Nigeria with an increasing population, realistically at six million [44]. Out of the slaughterhouses within the state, two major ones were purposively selected, namely the Nsukka and Kwata slaughterhouses. These two were selected given their capacity of processing more than $70 \%$ of goat carcass consumed in Enugu State [45].

The goat slaughter sections of the selected slaughterhouses were visited every other week for four months (December to January—dry season, and July to August-rainy/wet season). During each visit, about 5 goat carcasses, selected by a systematic random sampling method (one in five) were sampled. The first carcass selection was done by simple random sampling (toss of a coin). Thereafter, every fifth goat slaughtered was sampled. For each selected carcass, the sex was noted and the age estimated by the dentition method as described by Pace and Wakeman [46]. Thereafter, about $25 \mathrm{~g}$ each for kidney, liver and thigh muscle tissues were collected, separately packaged, labelled and transported to the laboratory of the National Centre for Energy Research and Development, University of Nigeria, Nsukka for the detection and quantification of As, $\mathrm{Cd}$ and $\mathrm{Pb}$. The tissues' collection and packaging was done with chemically cleaned instruments and the samples stored at freezing conditions $\left(-20^{\circ} \mathrm{C}\right)$ before the analysis. A total of 450 meat samples (150 each for kidney, liver and muscle tissues) from 150 randomly selected goat carcasses were analyzed.

\subsection{Sample Preparation for Digestion}

The frozen meat samples were allowed to thaw at room temperature $\left(25-30{ }^{\circ} \mathrm{C}\right)$. Fat tissue components of the meat were manually removed and about $10 \mathrm{~g}$ oven-dried (Carbolite Gero, Pennsylvania, PA, USA) to constant weight at $\sim 70^{\circ} \mathrm{C}$. The dried sample was granulated with mortar and piston (Changsha Jinto Co., Hunan, China), and was now ready for digestion and toxic metal determination.

\subsection{Digestion and Toxic Metal Determinations}

Wet digestion of the meat samples and subsequent analysis (Flame Atomic Absorption Spectrophotometry) for the presence of the THMs was performed as described by Nwude et al. [47]. Briefly, for each sample, $\sim 3 \mathrm{~g}$ was weighed into a $100 \mathrm{~mL}$ digestion flask (Global spec., New York, NY, USA), then $30 \mathrm{~mL}$ of aqua regia [mixture of concentrated $\mathrm{HNO}_{3}$ (Sigma-Aldrich Corp., Missouri, MO, USA) and $\mathrm{HCl}$ (Sigma-Aldrich Corp., Missouri, MO, USA) in the ratio of 1:3 was added to digest the sample in a fume-cupboard at $\sim 80^{\circ} \mathrm{C}$ until a clear solution was obtained. The solution was then cooled, filtered into a standard volumetric flask using size 42 Whatman's filter paper and made up to the $100 \mathrm{~mL}$ mark with deionized water. Thereafter, each solution was analyzed by flame atomic absorption spectrophotometry (AA-7000 Shimadzu, Kyoto, Japan; ROM 1.01) for the presence of $\mathrm{As}, \mathrm{Cd}$ and $\mathrm{Pb}$ at their respective wavelengths.

\subsection{Identification of Operational Parameters}

The meat samples were quantitatively analysed for the THMs using the calibration curve method. Multi-element continuous calibration verification (CCV) standard 1, $100 \mathrm{~mL}$ (4400-010100-) (CPI International, California, CA, USA) was used to check the continued validity of the initial calibration. For each metal analysis, a blank sample solution was used to calibrate the instrument before testing the samples. Standard solution for each of the metal was prepared and fed into the spectrophotometer for automatic plotting of each analyses respective calibration curves. The elemental analysis in each of the samples was carried out in duplicates, and the average value computed and recorded.

The limits of detection (LODs) were calculated as the concentration corresponding to three times the standard deviation (SD) of blanks, whereas the limits of quantification (LOQs) were computed as 10 times the SD of reagent blanks. Certified analytical grades of 
As, $\mathrm{Cd}$ and $\mathrm{Pb}$ (from Sigma-Aldrich ${ }^{\circledR}$, Darmstadt, Germany) were analyzed, and the result compared with the label concentrations.

All other chemicals and reagents used in this study were of analytical grade. Glassware were thoroughly washed with detergent and copiously rinsed with deionized water before use. Prior to the analysis, the qualitative and quantitative accuracy of the spectrophotometer was determined via metal recovery test (MRT). Certified reference materials, DORM-4 fish protein (National Research Council, Ottawa, ON, Canada), was used for the recovery.

The MRT also involved spiking analysed samples with a known quantity of each of the THMs. The spiked samples were subjected to chemical digestion as earlier described before the resultant solution was analysed for recovery and quantification of the metals. The operational parameters used for quantification of the metals, $\mathrm{As}, \mathrm{Cd}$ and $\mathrm{Pb}$, are as presented in Table 1.

Table 1. Operational parameters used for quantification of arsenic, cadmium and lead in edible tissues of goats slaughtered for human consumption in Enugu State, Nigeria.

\begin{tabular}{cccc}
\hline \multirow{2}{*}{ Parameter } & \multicolumn{3}{c}{ Heavy Metals } \\
\cline { 2 - 4 } & Arsenic & Cadmium & Lead \\
\hline Wavelength $(\mathrm{nm})$ & 193.7 & 228.8 & 283.3 \\
Slit with $(\mathrm{nm})$ & 0.7 & 0.7 & 0.7 \\
Limit of detection $\left(\mathrm{mg} \mathrm{kg}^{-1}\right)$ & 0.0005 & 0.0001 & 0.0001 \\
Limit of quantification $\left(\mathrm{mg} \mathrm{kg}^{-1}\right)$ & 0.002 & 0.001 & 0.001 \\
Metal recovery range $(\%)$ & $98-101.4$ & $98.2-101.5$ & $97-100.9$ \\
\hline
\end{tabular}

\subsection{Health Risk Assessment}

The health risk assessment involved the measurements of estimated daily intake, target hazard quotient, hazard index, and target cancer risk. These were carried out with a view to estimate the various health effects associated with consumption of THMs in the meats. These are described below:

\subsubsection{Estimated Daily Intake (EDI)}

The EDI of $\mathrm{As}, \mathrm{Cd}$ and $\mathrm{Pb}$ through consumption of goat carcass in the study area were determined using the formula: $\mathrm{EDI}=[\mathrm{C} \times \mathrm{QMC}] / \mathrm{BW}$ as described by the United States Environmental Protection Agency (USEPA) [48]; where C = mean concentration of the specific metal in the meat $(\mathrm{mg} / \mathrm{kg})$ and $\mathrm{BW}=$ average body weight $(\mathrm{kg})$. The QMC is the estimated quantity of goat carcass consumed daily $(\mathrm{g})=36 \mathrm{~g}$ as determined by survey of 104 randomly selected (goat carcass) consumers at slaughterhouses and meat markets in the study area. The average BW of children ( $0-17$ years) and adults ( $\geq 18$ years) were assumed to be $30 \mathrm{~kg}$ and $60 \mathrm{~kg}$ as set by USEPA [48]. The computed EDI values were then compared with the respective provisional tolerable daily intake (PTDI), of the respective THMs, which are amounts of the metals that can be ingested daily over a lifetime without appreciable health risk, as set by the joint Food and Agriculture Organization of the United Nations and World Health Organization (FAO/WHO) expert committee [49].

\subsubsection{Target Hazard Quotient (THQ)}

The THQ, which is the non-carcinogenic health risks posed by consumption of the respective THMs was estimated as recommended by the US environmental protection agency [48]; using the formula: THQ $=[(\mathrm{Ef} \times \mathrm{Ed} \times \mathrm{QMC} \times \mathrm{C}) /(\mathrm{RfD} \times \mathrm{BW} \times \mathrm{Et})] \times 10^{-3}$. $\mathrm{The} \mathrm{Ef}=$ exposure frequency in days (365), $\mathrm{Ed}=$ exposure duration in a life time (70 years), $\mathrm{QMC}=$ quantity of goat carcass consumed $(\mathrm{g})$, and $\mathrm{C}=$ mean concentration of the heavy metal $(\mathrm{mg} / \mathrm{kg})$. The RfD = oral reference dose of the metals was set by the USEPA [48] at $4 \times 10^{-3} \mathrm{mg} / \mathrm{kg} /$ day for $\mathrm{Pb}, 1.0 \times 10^{-3} \mathrm{mg} / \mathrm{kg} /$ day for $\mathrm{Cd}$ and $3 \times 10^{-3} \mathrm{mg} / \mathrm{kg} /$ day for As. The BW= body weight (60 $\mathrm{kg}$ for an average adult) while $\mathrm{Et}=$ lifetime exposure 
(365 day $\times 70$ years). The 70 years assumed for Ed and Et as well as the 365 days adopted for Ef were as recommended by the agency. If the calculated THQ value is $<1$, there is very little or no non-carcinogenic health risk. However, if the value is $\geq 1$, then there is a possibility that non-carcinogenic adverse health effects may ensue following the (goat) meat consumption.

\subsubsection{Hazard Index (HI)}

The facts that one food (meat) may be contaminated with multiple THMs and the consumption of the meat may result in simultaneous exposure to the metals make determination of $\mathrm{HI}$ imperative. The HI which is the summation of the individual THQs of the THMs detected in the meat was calculated as follows: $\mathrm{HI}=\mathrm{THQAs}+\mathrm{THQCd}+\mathrm{THQPb}$. When $H I$ value is $\geq 1$, it foretells that there is possibility of non-carcinogenic adverse health effects while values that are $<1$ depict very little or no non-carcinogenic effect.

\subsubsection{Target Cancer Risk (TCR)}

The TCR, which assesses the potential carcinogenic risks associated with lifetime exposure to carcinogens, was calculated as described by Naseri et al. [50] using the formula: $\mathrm{TCR}=\mathrm{CSF} \times \mathrm{EDI}$. The CSF is the cancer slope factor set at $0.008 \mathrm{mg} / \mathrm{kg} /$ day for $\mathrm{Pb}$, $0.38 \mathrm{mg} / \mathrm{kg} /$ day for $\mathrm{Cd}$ and $1.5 \mathrm{mg} / \mathrm{kg} /$ day for As by the US Environmental Protection Agency [48].

\subsection{Statistical Analysis}

One-way analysis of variance (ANOVA) was applied to establish the differences in concentrations of metals in the tissues. Chi-square or Fisher's exact test (as may be automatically highlighted by the software) was applied to determine if any significant associations existed between the occurrence of THMs and meat organs, age, sex and season. The emergent data have been presented in terms of mean values \pm standard error of mean (SEM). The level of statistical significance was set at $p<0.05$ (95\% confidence interval). GraphPad Prism ${ }^{\circledR}$ software, version 8.4.3 (GraphPad ${ }^{\circledR}$ Inc., San Diego, California, CA, USA) was used to do the data analysis.

\section{Results}

\subsection{Detection of Toxic Heavy Metals in Goat Carcasses}

The percentage (\%) detection of toxic heavy metals (THMs) in goat carcasses $(n=150)$ processed for human consumption in Enugu State, Nigeria, is shown in Table 2. At least one of the three THMs was detected in 56\% (84/150) of the carcasses.

Table 2. Percentage (\%) detection of toxic heavy metals (THMs) in goat carcasses $(n=150)$ processed for human consumption in Enugu State, Nigeria.

\begin{tabular}{ccc}
\hline $\begin{array}{c}\text { Detection Status of Toxic Heavy } \\
\text { Metals in Goat Carcasses }\end{array}$ & $\begin{array}{c}\text { Number of Goat } \\
\text { Carcasses }\end{array}$ & $\begin{array}{c}\text { Percentage (\%) of Goat } \\
\text { Carcasses }\end{array}$ \\
\hline $\begin{array}{c}\text { Toxic heavy metals or metalloids } \\
\text { detected }\end{array}$ & 84 & 56 \\
$\begin{array}{c}\text { No Toxic heavy metals or } \\
\text { metalloids detected } \\
\text { Total }(n)\end{array}$ & 66 & 44 \\
\hline
\end{tabular}

The statistical prevalence of the three THMs in goat carcasses $(n=450)$ processed for human consumption in Enugu State, Nigeria, is shown in Table 3. Cadmium, As and $\mathrm{Pb}$ were detected in 58.7\% (264/450), 56\% (252/450), and 32\% (144/450) of the meat cuts, respectively. Apparent in most of the organs (kidney, liver and muscle), all three THMs, As, $\mathrm{Cd}$ and $\mathrm{Pb}$ were statistically different $(p=0.043)$. 
Table 3. Statistical prevalence of toxic heavy metals (THMs) in goat carcasses $(n=450)$ processed for human consumption in Enugu State, Nigeria.

\begin{tabular}{ccccc}
\hline THMs & Number Positive & Prevalence & $\chi^{2}$-Value & $p$-Value \\
\hline Arsenic $(\mathrm{As})$ & 252 & 56 & & \\
Cadmium $(\mathrm{Cd})$ & 264 & 58.7 & 12.2 & 0.043 * \\
Lead $(\mathrm{Pb})$ & 144 & 32 & & \\
\hline * Denotes statistical significance, Chi-square test; GraphPad Prism ${ }^{\circledR}$ version 8.4.3.
\end{tabular}

\subsection{Distribution of THMs in Goat Carcasses from Organs to Epidemiological Variables}

The organs $(n=150)$ distributions of THMs above the maximum permissible limits in goats carcasses processed for human consumption in Enugu State, Nigeria, is shown in Table 4. Arsenic was detected in amounts above the WHO permissible levels in $24 \%(36 / 150)$ of the kidney, $28 \%(42 / 150)$ of the liver and $25.3 \%(38 / 150)$ of the muscle tissues. However, excessive amounts of Cd were recorded in $2.7 \%(4 / 150), 1.3 \%(2 / 150)$ and $0.7 \%(1 / 150)$ of the kidney, liver and muscle tissues, respectively. Overall, preponderance of $\mathrm{As}$ in the meats appeared more compared to $\mathrm{Cd}$ or $\mathrm{Pb}$. Significant organ distributions of As $\left(p=0.041, \chi^{2}\right.$-value $\left.=6.4\right)$ and $C d\left(p=0.000, \chi^{2}\right.$-value $\left.=15\right)$ were apparent, above the MPL.

Table 4. Organs $(n=150)$ distributions of toxic heavy metals (THMs) above the maximum permissible limits (MPL) in goats carcasses processed for human consumption in Enugu State, Nigeria.

\begin{tabular}{|c|c|c|c|c|}
\hline THMs & Organs & $\begin{array}{c}\text { Number } \\
\text { Contaminated Above } \\
\text { MPL (\%) } * *\end{array}$ & $x^{2}$-Value & $p$-Value \\
\hline \multirow{4}{*}{ Arsenic (As) } & Kidney & $36(24)$ & \multirow{4}{*}{6.4} & \multirow{4}{*}{0.041 * } \\
\hline & Liver & $42(28)$ & & \\
\hline & Muscle & $38(25.3)$ & & \\
\hline & Kidney & $4(2.7)$ & & \\
\hline \multirow[t]{3}{*}{ Cadmium (Cd) } & Liver & $2(1.3)$ & \multirow[t]{3}{*}{15} & \multirow[t]{2}{*}{0.000 * } \\
\hline & Muscle & $1(0.7)$ & & \\
\hline & Kidney & $22(14.7)$ & & \multirow{3}{*}{0.724} \\
\hline \multirow[t]{2}{*}{ Lead $(\mathrm{Pb})$} & Liver & $22(14.7)$ & \multirow[t]{2}{*}{0.65} & \\
\hline & Muscle & $24(16)$ & & \\
\hline
\end{tabular}

* Denotes statistical significance, Fisher's exact test; GraphPad Prism ${ }^{\circledR}$ version 8.4.3; ** value outside bracket refers to the actual number of samples; value inside bracket refers to percentage value from total number.

The mean concentration of THMs specific to organs of goat carcasses processed for human consumption in Enugu State, Nigeria, is shown in Table 5. The metal concentrations ranged between 0.00 and $1.55 \mathrm{mg} / \mathrm{kg}$ for $\mathrm{Pb}, 0.00$ and $1.807 \mathrm{mg} / \mathrm{kg}$ for As, as well as 0.02 and $0.829 \mathrm{mg} / \mathrm{kg}$ for $\mathrm{Cd}$. The mean concentrations of As were $0.533 \pm 0.103,0.569 \pm 0.091$ and $0.452 \pm 0.081 \mathrm{mg} / \mathrm{kg}$ for kidney, liver and muscle tissues, respectively. However, that of $\mathrm{Pb}$ was $0.480 \pm 0.377,0.450 \pm 0.238$ and $0.820 \pm 0.388 \mathrm{mg} / \mathrm{kg}$ respectively for kidney, liver and muscle tissues. Moreover, no significant differences $(p>0.05)$ in THMs appeared across the organs studied.

Table 5. Mean concentration of toxic heavy metals (THMs) specific to organs of goat carcasses processed for human consumption in Enugu State, Nigeria.

\begin{tabular}{cccccc}
\hline \multirow{2}{*}{ THMs } & \multirow{2}{*}{$\begin{array}{c}\text { Range Conc. } \\
(\mathbf{m g} / \mathbf{k g})\end{array}$} & \multicolumn{2}{c}{ Mean Concentrations \pm SEM (mg/kg) in Organs } & M-Value \\
\cline { 3 - 5 } & & Kidney & Liver & Muscle & \\
\hline Arsenic $(\mathrm{As})$ & $0.00-1.81$ & $0.53 \pm 0.10$ & $0.57 \pm 0.09$ & $0.45 \pm 0.08$ & 0.651 \\
Cadmium $(\mathrm{Cd})$ & $0.020-0.83$ & $0.06 \pm 0.32$ & $0.02 \pm 0.00$ & $0.02 \pm 0.00$ & 0.270 \\
Lead $(\mathrm{Pb})$ & $0.00-1.55$ & $0.48 \pm 0.38$ & $0.45 \pm 0.24$ & $0.82 \pm 0.39$ & 0.697 \\
\hline
\end{tabular}


The distribution of THMs found in goat carcasses $(n=150)$ according to various epidemiological variables is shown in Table 6. All the three toxic metals were prevalent in older ( $\geq 4$ years) goat carcasses than in those aged less than four years. The age of the carcasses were statistically different $(p<0.05)$ across all three THMs detected (Table 6). The frequency of $\mathrm{Cd}$ detection appeared more in does/nannies (females) compared with the bucks (males). No statistical significance $(p>0.05)$ existed between the sex of the goats and the presence of $\mathrm{Cd}$ in the carcasses tested. With respect to seasonal distribution, the frequency of As and $\mathrm{Pb}$ detected during the rainy (wet) season differed significantly $(p<0.05)$ compared with those detected during the dry season. Other details on the epidemiological distributions of the metals are shown in Table 6 below.

Table 6. Distribution of toxic heavy metals/metalloids (THMs) according to various epidemiological variables in goat carcasses $(n=150)$ processed for human consumption in Enugu State.

\begin{tabular}{|c|c|c|c|c|c|c|c|}
\hline THMs & $\begin{array}{l}\text { Epidemiological } \\
\text { Variables }\end{array}$ & $\begin{array}{l}\text { Number } \\
\text { Sampled }\end{array}$ & $\begin{array}{l}\text { Number } \\
\text { Positive }\end{array}$ & Prevalence & Odds Ratio & $95 \% \mathrm{CI}$ & $p$-Value \\
\hline \multirow{9}{*}{ Arsenic } & & & & Age & \multirow[b]{3}{*}{0.39} & \multirow[b]{3}{*}{$0.20-0.76$} & \multirow[b]{3}{*}{$0.005 *$} \\
\hline & $<4$ years & 70 & 31 & 44.3 & & & \\
\hline & $\geq 4$ years & 80 & 53 & 66.3 & & & \\
\hline & & & & Sex & \multirow[b]{3}{*}{1.1} & & \\
\hline & Male & 66 & 38 & 57.6 & & \multirow[b]{2}{*}{$0.56-2.10$} & \multirow[b]{2}{*}{0.730} \\
\hline & Female & 84 & 46 & 54.8 & & & \\
\hline & & & & Season & \multirow{3}{*}{1.5} & & \\
\hline & Wet/rainy & 63 & 39 & 61.9 & & \multirow[b]{2}{*}{$0.78-2.9$} & \multirow[b]{2}{*}{0.215} \\
\hline & Hot/dry & 87 & 45 & 51.7 & & & \\
\hline \multirow{9}{*}{ Cadmium } & & & & Age & \multirow{3}{*}{0.32} & \multirow{3}{*}{$0.16-0.63$} & \multirow{3}{*}{0.001 * } \\
\hline & $<4$ years & 70 & 34 & 48.6 & & & \\
\hline & $\geq 4$ years & 80 & 50 & 62.5 & & & \\
\hline & & & & Sex & & & \\
\hline & Male & 66 & 32 & 48.5 & \multirow{2}{*}{0.58} & \multirow{3}{*}{$0.30-1.11$} & \multirow{2}{*}{0.103} \\
\hline & Female & 84 & 52 & 61.9 & & & \\
\hline & & & & Season & & & \\
\hline & Wet/rainy & 63 & 44 & 69.8 & \multirow{2}{*}{2.4} & \multirow{2}{*}{$1.1-4.5$} & \multirow{2}{*}{0.018 * } \\
\hline & Hot/dry & 87 & 40 & 45.0 & & & \\
\hline \multirow{9}{*}{ Lead } & & & & Age & \multirow[b]{3}{*}{2.4} & & \\
\hline & $<4$ years & 70 & 47 & 67.1 & & \multirow{3}{*}{$1.2-4.6$} & \multirow[b]{2}{*}{0.010 * } \\
\hline & $\geq 4$ years & 80 & 37 & 46.3 & & & \\
\hline & & & & Sex & & & \\
\hline & Male & 66 & 34 & 51.5 & \multirow{3}{*}{0.72} & \multirow{3}{*}{$0.4-1.4$} & \multirow{3}{*}{0.327} \\
\hline & Female & 84 & 50 & 59.2 & & & \\
\hline & & & & Season & & & \\
\hline & Wet/rainy & 63 & 49 & 77.8 & \multirow{2}{*}{5.2} & \multirow{2}{*}{$2.5-10.8$} & \multirow{2}{*}{0.000 * } \\
\hline & Hot/dry & 87 & 35 & 40.2 & & & \\
\hline
\end{tabular}

* Denotes statistical significance, based on Chi-square test, $\mathrm{CI}=$ Confidence Interval.

\subsection{Health Risk Assessment of Toxic Heavy Metals/Metalloids (THMs) in Goat Carcasses}

The estimated daily intake (EDI) and target cancer risk (TCR) of THMs specific to children and adult consumers of goat carcasses processed in Enugu State, Nigeria, is shown in Table 7. The computed EDI for As in both the children and adult populations ranged between 0.271 and 0.640 , which exceeded the WHO's recommended PTDI. Similarly, the EDI values of $\mathrm{Pb}$ in both adult and children populations ranged between 0.270 and 0.984 , which were above the $\mathrm{WHO}^{\prime}$ s recommended PTDI. A similar trend was obtained for $\mathrm{Cd}$, except that the $0.009 \mathrm{EDI}$ value, computed for muscle tissue in the adult population, is less than the recommended PTDI. The calculated EDI values were generally higher for children than for the adult population. The TCR value obtained for $\mathrm{Pb}$ in muscle tissue was 1.4761. The target hazard quotient (THQ) and hazard index (HI) specific to children and adult consumers of goat carcass processed in Enugu State, Nigeria, is shown in Table 8. The THQ 
of all the THMs and in all the organs ranged between 0.009 and 0.246 . The HI value for each of the three metals was less than unity.

Table 7. Estimated daily intake (EDI) and target cancer risk (TCR) of toxic heavy metals (THMs) specific to children and adult consumers of goat carcass processed in Enugu State, Nigeria.

\begin{tabular}{cccccc}
\hline \multirow{2}{*}{ THMs } & \multirow{2}{*}{ Organs } & \multicolumn{2}{c}{ EDI } & \multicolumn{2}{c}{ TCR } \\
\cline { 3 - 6 } & & Children & Adult & Children & Adult \\
\hline \multirow{3}{*}{ Arsenic } & Kidney & $0.640^{*}$ & $0.320^{*}$ & 0.0051 & 0.0026 \\
& Liver & $0.683^{*}$ & $0.341^{*}$ & 0.0055 & 0.0027 \\
& Muscle & $0.542^{*}$ & $0.271^{*}$ & 0.0043 & 0.0022 \\
Cadmium & Kidney & $0.066^{*}$ & $0.033^{*}$ & 0.0251 & 0.0125 \\
& Liver & $0.022^{*}$ & $0.011^{*}$ & 0.0084 & 0.0042 \\
& Muscle & $0.019^{*}$ & 0.009 & 0.0072 & 0.0036 \\
\multirow{2}{*}{ Lead } & Kidney & $0.576^{*}$ & $0.288^{*}$ & 0.8640 & 0.4320 \\
& Liver & $0.540^{*}$ & $0.270^{*}$ & 0.8100 & 0.4051 \\
& Muscle & $0.984^{*}$ & $0.492^{*}$ & $1.47611^{* *}$ & 0.738 \\
\hline
\end{tabular}

* EDI values that exceeded the $\mathrm{WHO}^{\prime} \mathrm{s}$ provisional tolerable daily intake (PTDI). The PTDI for As $=0.003$ $\mathrm{mg} / \mathrm{kg} /$ day, $\mathrm{Cd}=0.001 \mathrm{mg} / \mathrm{kg} /$ day and $\mathrm{Pb}=0.002 \mathrm{mg} / \mathrm{kg} /$ day. ${ }^{* *}$ TCR value $>1=$ carcinogenic risk.

Table 8. Target hazard quotient (THQ) and hazard index (HI) specific to children and adult consumers of goat carcass processed in Enugu State, Nigeria.

\begin{tabular}{|c|c|c|c|c|c|c|c|c|}
\hline \multirow{3}{*}{ Organs } & \multicolumn{6}{|c|}{ THQ } & \multirow{2}{*}{\multicolumn{2}{|c|}{ HI }} \\
\hline & \multicolumn{2}{|c|}{ As } & \multicolumn{2}{|c|}{ Cd } & \multicolumn{2}{|c|}{$\mathrm{Pb}$} & & \\
\hline & Children & Adults & Children & Adults & Children & Adults & Children & Adults \\
\hline Kidney & 0.213 & 0.107 & 0.066 & 0.032 & 0.144 & 0.072 & 0.423 & 0.211 \\
\hline Liver & 0.228 & 0.114 & 0.022 & 0.011 & 0.135 & 0.068 & 0.385 & 0.193 \\
\hline Muscle & 0.182 & 0.091 & 0.019 & 0.009 & 0.246 & 0.123 & 0.447 & 0.223 \\
\hline
\end{tabular}

THQ or HI values less than one indicates no or very little non-carcinogenic health risk.

\section{Discussion}

The THMs were detected at a high rate in goat carcasses slaughtered for human consumption in this study (refer to Tables 2 and 3). This, in our opinion, might have a lot to do with the pollution status of the environment in which these goats were raised. The debate regarding the meats' toxicological safety therefore continues given the adverse health effects that the THMs pose. Notably, at least one of the three THMs has been detected in the goat carcasses at this current study (refer to Table 3). This, in our opinion, might be attributable to indiscriminate disposal of industrial effluents, or excessive agricultural use of agrochemicals that accumulated THMs in pastures, fodder plants, drinking water sources, which eventually entered the animal's tissues [18,32]. The contamination of grazing fields and water bodies with toxic metals can emanate from excessive use of organic fertilizers, the latter used to boost food production, and such agrochemicals may constitute heavy metals [51]. THMs bioaccumulating in plants enhances the possibility of (heavy metal) poisoning the herbivorous animals (that graze the plants), particularly goats. In mind that bio-magnification of THMs increases with trophic level [27], human that consume the contaminated meat are at greater risk of heavy metal poisoning and would suffer its deleterious health effects. Indeed, the implications of THMs bio-accumulation in edible plant and animal tissues are detrimental to food safety and endanger public health $[17,32,52]$.

The frequent or inappropriate use of acaricides is among anthropogenic pathways that accounts for the high rate of the metals in goat meats. Such chemicals used to treat ectoparasite in FPAs may lead to tissue uptake of THMs, particularly As usually constituent of most ecto-parasiticide [3,53]. Extensive and semi-intensive types of goat husbandry methods, widely practiced in most developing countries, greatly expose the small ruminants to ectoparasitism and hence, frequent acaricidal treatments [54]. This might probably 
explain the preponderance of As in the sampled goat carcass compared to $\mathrm{Cd}$ or $\mathrm{Pb}$ (refer to Tables 4 and 5) since most acaricides contain As [3,53]. Given their voracious and low-grazing feeding habits, goats remain naturally predisposed to heavy metal/metalloid intoxication, given the possibilities of either accidental geophagia, ingestion during grazing on a contaminated pastureland, and or drinking from THM-contaminated water body.

The prolonged bioaccumulation of THMs with ageing (of the animal) particularly in older goats [17] might likely be responsible for the increased distribution of As and $\mathrm{Cd}$ in the chevon of this current study (refer to Table 6). Especially at birth of FPAs, little to zero quantity of THMs may be detected. However, THMs has been shown with potential to increasingly accumulate with ageing (in both animals and humans) [3]. THMs accumulating in the tissues of FPAs could associate with the excretion rate falling below the acquisition rate. The THMs would bind with biomolecules and cellular components to achieve stable bonds/complexes, which may not be easily excreted $[1,20,21]$. Besides, seasonal predisposition of $\mathrm{Cd}$ in the goat carcass (refer to Table 5) might be due to latter's predilection for green leafy vegetation (lush pasture) usually grazed during the rainy season $[55,56]$. The age-dependency and seasonality of THMs (refer to Table 6) offer useful epidemiological information, which has to be utilised so as to limit (THMs) contamination in goat meat. Chevon from young goats (less than four years) for human consumption could be a remedy, given that THMs increasingly accumulate with age [11-13,36]. Further, feeding goats concentrates or hay, rather than lush pasture, could help decrease THMs meat contamination in chevon. This is a strong proposition because THMs usually occupy the topsoil and lush pasture/fodder in contaminated pasturelands, particularly during the rainy season [56,57]. As goat production intensifies and cases of ectoparasitism rise, the frequency of acaricidal treatment will inevitably increase. Thus, to diminish the chances of meat contamination with THMs requires prudent use of heavy-metal-free acaricides to combat ectoparasites.

The fact that THMs were above the tolerance limits in goats slaughtered for human consumption (refer to Table 4) exemplifies the significant food safety and public health risks these metals do pose to the human population. For example, the exposures to excessive levels of $\mathrm{Pb}$ has been linked to such health concerns like distortions in hemoglobin synthesis, abnormalities in erythropoiesis and derangements in CNS functions [20,58], attention deficit/hyperactivity disorder, low intelligent quotient and dysfunctional behaviour in children and young adults $[59,60]$. In adults, there could be hypertension, cardiovascular diseases, mental retardation, behavioural disorders, neuropsychological deficits, early cognitive decline and other neurological disorders in cases of lead-poisoning [61-63].

We are concerned about the higher percentage of As dominating the THMs in the goat carcass at this current study given the potential adverse health effects it may pose to humans (refer to Tables 2 and 4-6). It is equally this kind of food safety concerns associated with the accumulation of THMs in edible animal products that have made the international food safety regulatory authorities especially those under the European Commission (EC) [29] to set maximum permissible limits (MPL), or safety limits/tolerance levels, particularly for the metals in foods of animal origin. In line with this, if the level of THMs found in foods, especially edible animal proteins, are above the stipulated MPL, it would be deemed 'unacceptable' and 'illegal' given the adverse/substantial health effects/risks its exposures pose to consumer safety. If the human were to be exposed to THMs via the food chain, there are substantial health risks such toxic metals would pose, which would bring about adverse health effects [1,30-32].

Moreover, the As metalloid is well known to pose high health risks and remains highly carcinogenic. In fact, it is a very notable carcinogen understood to cause cancer following gastrointestinal or respiratory exposure [64-66]. Exposure to As was believed to have led to cancers of the skin, lungs, and bladder, according to the International Agency for Research on Cancer [67]. Although the exact mechanism of As-induced carcinogenesis appears not yet fully understood, there are a number of existing hypotheses that have been proposed that underscores the pathophysiology of its (As) toxicity. Examples include the 
induction of chromosome abnormalities, oxidative stress, altered DNA repair and altered DNA methylation patterns $[65,67]$. Monomethylarsonic acid, which is a major product of biomethylation of arsenic, is crucial in the arsenic-induced carcinogenesis $[1,66,68]$.

The adverse human health effects of $\mathrm{Cd}$ metal, on the other hand, should not be underestimated. For instance, $\mathrm{Cd}$ exposure has been shown to bring about both taste and smell dysfunctions in China [69]. Excessive Cd level in the body can cause hepatotoxicity, osteoporosis, teratogenicity, neurotoxicity and immunosuppression due to apoptosis induction in normal human mononuclear cells [70,71]. The $\mathrm{Cd}$ metal has been implicated in the pathogenesis and pathophysiology of type-2 diabetes mellitus [8,72]. Induction of oxidative stress seems to be the major mechanism for the onset of deleterious health effects associated with Cd. Oxidative stress refers to tissue accumulation of reactive oxygen species (ROS) due to the decrease in the body's ability to detoxify these reactive products following an assault. The ROS, to accrue from oxidative stress, could facilitate type-2 diabetes mellitus by decreasing pancreatic insulin production and increasing insulin resistance [5,71,73,74].

The mean concentrations of THMs in some of goat carcass samples, being above the safe limits, could result in adverse health effects. In particular, the amounts of As and $\mathrm{Cd}$ of this current study fell below $2.122 \mathrm{mg} / \mathrm{kg}(\mathrm{Cd})$ and $(34.54 \mathrm{mg} / \mathrm{kg}$ (As) reported by Kulawik et al. [75] in Poland. However, the mean amounts of the metals detected were higher that the range concentrations of $0.001-0.104 \mathrm{mg} / \mathrm{kg}$ for As, $0.015-0.420 \mathrm{mg} / \mathrm{kg}$ for $\mathrm{Cd}$ and $0.003-0.100 \mathrm{mg} / \mathrm{kg}$ for $\mathrm{Pb}$ reported by Antoine et al. [76] in Jamaica. In Nigeria, the mean amounts of the THMs found were higher than the range concentrations of 0.014$1.37 \mathrm{mg} / \mathrm{kg}(\mathrm{Pb})$ and $0.00-0.00017 \mathrm{mg} / \mathrm{kg}(\mathrm{Cd})$ detected in street-vended foods in Benin City and Umunede [77]. On the contrary, our data fell below $28.28 \mathrm{mg} / \mathrm{kg}(\mathrm{Pb})$ and $0.38 \mathrm{mg} / \mathrm{kg}$ (Cd) found in chicken in Zamfara State [32]. The differences between data of current study and above mentioned reports could be due to variations in the levels of environmental contamination with the THMs. Despite these differences, the hazards posed by the THMs in foods remain vital given the public health risks even in minute quantities.

The health risk assessment of this current work has substantiated a very important information regarding $\mathrm{Pb}$ linked to children populations. That is, the TCR value of 1.476 computed for $\mathrm{Pb}$ in muscle tissues (refer to Table 7) might pose risk of cancer among children who consume goat carcass muscles from Enugu State. This is very relevant given that $\mathrm{Pb}$ toxicity and lead-poisoning cases in Nigerian children have been severally reported [78-83]. However, unlike the adult population, children in Enugu State may likely not be consuming chevon particularly on a daily basis. Hence, there is a high chance that any possible health hazard specific to children populations may not arise. Importantly, the HI and THQ values recorded less than one, thus, the consumption of chevon in the study area carries very little or no non-carcinogenic risk. Although most EDI values were above the PTDI set by the WHO for the respective THMs (refer to Tables 7 and 8), adverse public health problems following the consumption of goat carcass in Enugu State may not be much because, according to Ladele et al. [84] beef meat has for long been more consumed over goat carcass. Despite this, screening tests against THMs in Nigerian slaughterhouses should be instituted so as to ascertain the toxicological safety of meats intended for human consumption.

\section{Conclusions}

The detection, distribution, and health risk assessment of THMs, specifically As, Cd, and $\mathrm{Pb}$ in goat carcasses processed for human consumption in South-Eastern Nigeria, with reference to Enugu State, were successfully investigated. For emphasis, the current status of goat carcass contamination with THMs, and insights into its toxicological safety, as it pertains to the meat consumers, have been successfully discussed. We have demonstrated that excessive levels of $\mathrm{As}, \mathrm{Cd}$ and $\mathrm{Pb}$ can be detected in edible tissues of goat carcasses processed for human consumption, specific to the South-Eastern part of Nigeria. The presence of excessive levels of $\mathrm{As}, \mathrm{Cd}$ and $\mathrm{Pb}$ poses significant health risks to the meat consumers considering the adverse health effects and bio-accumulative potentials of THMs. We also showed that the EDI for all the metals/metalloids were above the PDTI set by 
the WHO of the United Nations. Despite the high EDI values, the possible consequential health problems may not be too much since chevon appears not consumed daily. The THQ and $\mathrm{HI}$ for all the three THMs in all the organs fell below unity, which was indicative of little or no non-carcinogenic risks.

It is essential to reiterate herein that as THMs increasingly build up in the environment, either from contamination of drinking water sources and pastureland, or excessive use of acaricides used to treat ectoparasites involved in goat production, a number of health risk issues would continually arise. When THMs accumulate in this context, they will be detected in goat carcass being processed and sold for human consumption, and it is only through studies like this, herein, would the health risks it pose be conveyed. Indeed, the cumulated health effect/risks on those who consume the infected chevon, from oxidative stress, inhibition of enzymes, organ damage, cancer, poor sight/taste/smell, among others, can be significant. We have, at this current study, acquired an improved understanding about the current status of goat carcass contamination with THMs, and this is specific to the South-Eastern Nigeria. We have also provided additional insights about its toxicological safety. Indeed, the information assembled herein can contribute in building the policy framework and formulation regarding public health safety in Nigerian slaughterhouses.

Essentially: at the slaughterhouse level, the processed meats should be increasingly screened for chemical (residue) contamination, particularly THMs, to ensure compliance with internationally recognized safety limits. Given the adverse health problems associated with THMs' contamination of goat carcass, there is need for the direction of future studies to evaluate how the indiscriminate use of agrochemicals and other anthropogenic activities impact on pastureland and drinking water sources used for livestock production. Another direction of future studies should be on assessing how farmers over time periods and at various locations have used agrochemicals on the pastureland/goat production, so as to decipher the prevailing factors that impact THMs on its excessive use with respect to livestock production, which would have health risk implications on emergent meat product and consumer safety. The evaluation of such factors would require robust statistical tools, regression models, and principal component analysis, to offer predictive location/timerelated insights, which would be useful for the Nigeria federal/state government public health-THMs policy framework. Through this, the environmental contamination by THMs would be minimised, even in meat products.

Author Contributions: Conceptualization, E.O.N., E.V.E. and C.G.O.; data curation, E.O.N., E.V.E., C.G.O., C.U.O., I.F.J., A.C.O. and C.O.R.O.; formal analysis, E.O.N., E.V.E. and C.G.O.; funding acquisition, C.O.R.O.; investigation, E.O.N., E.V.E. and C.G.O.; methodology, E.O.N., E.V.E., C.G.O., C.U.O., I.F.J., A.C.O. and C.O.R.O.; resources, E.O.N., E.V.E. and C.G.O., C.U.O. and C.O.R.O.; software, C.U.O. and C.O.R.O.; validation, C.G.O., C.U.O., I.F.J., A.C.O. and C.O.R.O.; visualization, E.O.N., E.V.E., C.G.O., C.U.O., I.F.J., A.C.O. and C.O.R.O.; writing-original draft,. E.O.N., E.V.E. and C.G.O.; writing-review and editing, C.U.O., I.F.J., A.C.O. and C.O.R.O. All authors have read and agreed to the published version of the manuscript.

Funding: Publication financed by the project UPWR 2.0: International and Interdisciplinary Programme of Development of Wrocław University of Environmental and Life Sciences, co-financed by the European Social Fund under the Operational Program Knowledge Education Development, under contract no. POWR.03.05.00-00-Z062/18 of 4 June 2019.

Institutional Review Board Statement: Not applicable.

Informed Consent Statement: Not applicable.

Data Availability Statement: Data sharing not applicable.

Acknowledgments: The author C.O.R.O. acknowledges financial support from Wroclaw University of Environmental and Life Sciences, Wroclaw, Poland.

Conflicts of Interest: The authors declare no conflict of interest. 


\section{References}

1. Jaishankar, M.; Tseten, T.; Anbalagan, N.; Mathew, B.B.; Beeregowda, K.N. Toxicity, mechanism and health effects of some heavy metals. Interdiscip. Toxicol. 2014, 7, 60-72. [CrossRef] [PubMed]

2. Renwick, A.G. Toxicology of Micronutrients: Adverse Effects and Uncertainty. J. Nutr. 2006, 136, 493S-501S. [CrossRef] [PubMed]

3. Raikwar, M.K.; Kumar, P.; Singh, M. Toxic effect of heavy metals in livestock health. Vet. World 2008, 1, 28-30. [CrossRef]

4. Marouf, B.H. Association between serum heavy metals level and cancer incidence in Darbandikhan and Kalar Ar-ea, Kurdistan Region, Iraq. Niger J. Clin. Pract. 2018, 21, 766-771. [CrossRef] [PubMed]

5. Ezedom, T.; Asagba, S.; Tonukari, N.J. Toxicological effects of the concurrent administration of cadmium and arsenic through the food chain on the liver and kidney of rats. J. Basic Appl. Zoöl. 2020, 81, 1-12. [CrossRef]

6. Nkwunonwo, U.C.; Odika, P.O.; Onyia, N.I. A Review of the Health Implications of Heavy Metals in Food Chain in Nigeria. Sci. World J. 2020, 2020, 1-11. [CrossRef] [PubMed]

7. Akoto, O.; Teku, J.A.; Gasinu, D. Chemical characteristics and health hazards of heavy metals in shallow groundwater: Case study Anloga community, Volta Region, Ghana. Appl. Water Sci. 2019, 9, 36. [CrossRef]

8. Little, B.B.; Reilly, R.; Walsh, B.; Vu, G.T. Cadmium is associated with type 2 diabetes in a superfund site lead smel-ter community in Dallas, Texas. Int. J. Environ. Res. Public Health 2020, 17, 4558. [CrossRef] [PubMed]

9. Järup, L. Hazards of heavy metal contamination. Br. Med. Bull. 2003, 68, 167-182. [CrossRef] [PubMed]

10. Cheremisinoff, N.P. Agency for Toxic Substances and Disease Registry (ATSDR); JohnWiley \& Sons, Inc.: Hoboken, NJ, USA, 2006; pp. 83-93.

11. Pamphlett, R.; Bishop, D.P.; Kum, J.S.; Doble, P.A. Age-related accumulation of toxic metals in the human locus ce-ruleus. PLoS ONE 2018, 13, e0203627. [CrossRef] [PubMed]

12. Tifarouine, L.; Aziz, F.; El Abidi, A.; Hichami, N.; Benmokhtar, S.; Badaoui, B.; Idrissi, H.R.; Fekhaoui, M.; Benhoussa, A. Influence of age on the bioaccumulation of heavy metals in Apodemus syl-vaticus at Merja Zerga lagoon, Morocco. Saudi J. Biol. Sci. 2019, 26, 1682-1688. [CrossRef]

13. Tchounwou, P.B.; Yedjou, C.G.; Patlolla, A.K.; Sutton, D.J. Heavy metal toxicity and the environment. Exp. Suppl. 2012, 101, 133-164. [PubMed]

14. Makridis, C.; Christos, S.; Nikolaos, R.; Nikolaos, G.; Loukia, R.; Stefanos, L. Transfer of heavy metal contaminants from animal feed to animal products. J. Agric. Sci. Technol. 2012, 2, 149-154.

15. Ogundiran, M.B.; Ogundele, D.T.; Afolayan, P.G.; Osibanjo, O. Heavy metals levels in forage grasses leachate and lactating cows reared around lead slag dumpsites in Nigeria. Int. J. Environ. Res. 2012, 6, 695-702.

16. Rajaganapa, V.; Xavier, F.; Sreekumar, D.; Mandal, P. Heavy Metal Contamination in Soil, Water and Fodder and their Presence in Livestock and Products: A Review. J. Environ. Sci. Technol. 2011, 4, 234-249. [CrossRef]

17. Bawuro, A.A.; Voegborlo, R.B.; Adimado, A.A. Bioaccumulation of heavy metals in some tissues of fish in lake Geri-yo, Adamawa State, Nigeria. J. Environ. Public Health 2018, 2018, 1854892. [CrossRef] [PubMed]

18. Tangahu, B.V.; Abdullah, S.R.S.; Basri, H.; Idris, M.; Anuar, N.; Mukhlisin, M. A Review on Heavy Metals (As, Pb, and Hg) Uptake by Plants through Phytoremediation. Int. J. Chem. Eng. 2011, 2011, 1-31. [CrossRef]

19. Udiba Udiba, U.; Hassan Diya'uddeen, B.; Odey Michael, O.; Bashir Inuwa, L.A.; Ade-Ajayi, A.B.F.; Ezike Nkechi, N.; Umar Shittu, M. Toxicological implications of grazing on forage grasses in Dereta Village, Zamfara. Arch. Appl. Sci. Res. 2013, 5, 151-158.

20. Abou, E.E.H.; Khalid, E.; Hamed, M.A. Toxicity of cadmium and copper and their effect on some biochemical pa-rameters of the marine fish, Mugil seheli. Egypt J. Aquat. Res. 2005, 31, 60-70.

21. Jan, A.T.; Azam, M.; Siddiqui, K.; Ali, A.; Choi, I.; Haq, Q.M.R. Heavy Metals and Human Health: Mechanistic Insight into Toxicity and Counter Defense System of Antioxidants. Int. J. Mol. Sci. 2015, 16, 29592-29630. [CrossRef] [PubMed]

22. Gorini, F.; Muratori, F.; Morales, M.A. The Role of Heavy Metal Pollution in Neurobehavioral Disorders: A Focus on Autism. Rev. J. Autism Dev. Disord. 2014, 1, 354-372. [CrossRef]

23. Koedrith, P.; Seo, Y.R. Advances in Carcinogenic Metal Toxicity and Potential Molecular Markers. Int. J. Mol. Sci. 2011, 12, 9576-9595. [CrossRef] [PubMed]

24. Briffa, J.; Sinagra, E.; Blundel, R. Heavy metal pollution in the environment and their toxicological effects on humans. Heliyon 2020, 6, e04691. [CrossRef] [PubMed]

25. Genchi, G.; Sinicropi, M.S.; Lauria, G.; Carocci, A.; Catalano, A. The Effects of Cadmium Toxicity. Int. J. Environ. Res. Public Health 2020, 17, 3782. [CrossRef] [PubMed]

26. Li, Q.; Liu, H.; Alattar, M.; Jiang, S.; Han, J.; Ma, Y.; Jiang, C. The preferential accumulation of heavy metals in different tissues following frequent respiratory exposure to PM2.5 in rats. Sci. Rep. 2015, 5, 16936. [CrossRef] [PubMed]

27. Mackay, D.; Celsie, A.K.D.; Arnot, J.A.; Powel, D.E. Influencing chemical biomagnification and trophic magnifica-tion factors in aquatic ecosystems: Implications for chemical hazard and risk assessment. Chemosphere 2016, 154, 99-108. [CrossRef] [PubMed]

28. Chebli, Y.; El Otmani, S.; Chentouf, M.; Hornick, J.-L.; Bindelle, J.; Cabaraux, J.-F.; Chebli, Y. Foraging Behavior of Goats Browsing in Southern Mediterranean Forest Rangeland. Animals 2020, 10, 196. [CrossRef] [PubMed]

29. European Commission (EC)—Commission of the European Communities. Commission Regulation (EC) No. 1881. Setting maximum levels for certain contaminants in foodstuffs. Off. J. Eur. Comm. 2006, 364, 24. 
30. Kim, H.S.; Kim, Y.J.; Seo, Y.R. An Overview of Carcinogenic Heavy Metal: Molecular Toxicity Mechanism and Prevention. J. Cancer Prev. 2015, 20, 232-240. [CrossRef] [PubMed]

31. Buha, A.; Wallace, D.; Matovic, V.; Schweitzer, A.; Oluic, B.; Micic, D.; Djordjevic, V. Cadmium Exposure as a Putative Risk Factor for the Development of Pancreatic Cancer: Three Different Lines of Evidence. Biomed. Res. Int. 2017, 2017, 1-8. [CrossRef] [PubMed]

32. Orisakwe, O.E.; Oladipo, O.O.; Ajaezi, G.C.; Udowelle, N.A. Horizontal and Vertical Distribution of Heavy Metals in Farm Produce and Livestock around Lead-Contaminated Goldmine in Dareta and Abare, Zamfara State, Northern Nigeria. J. Environ. Public Health 2017, 2017, 1-12. [CrossRef] [PubMed]

33. Food and Agriculture Organization of the United Nations. Available online: http://www.fao.org/faostat/en/\#compare (accessed on 11 March 2019).

34. Mazhangara, I.R.; Chivandi, E.; Mupangwa, J.F.; Muchenje, V. The Potential of Goat Meat in the Red Meat Industry. Sustainability 2019, 11, 3671. [CrossRef]

35. Alao, B.O.; Falowo, A.B.; Chulayo, A.; Muchenje, V. Consumers' Preference and Factors Influencing Offal Consumption in Amathole District Eastern Cape, South Africa. Sustainability 2018, 10, 3323. [CrossRef]

36. Cui, J.; Wu, B.; Halbrook, R.S.; Zang, S. Age-dependent accumulation of heavy metals in liver, kidney and lung tis-sues of homing pigeons in Beijing, China. Ecotoxicology 2013, 22, 1490-1497. [CrossRef] [PubMed]

37. Singh, R.; Gautam, N.; Mishra, A.; Gupta, R. Heavy metals and living systems: An overview. Indian J. Pharmacol. 2011, 43, 246-253. [CrossRef]

38. Ukah, B.U.; Igwe, O.; Ameh, P. The impact of industrial wastewater on the physicochemical and microbiological characteristics of groundwater in Ajao- Estate Lagos, Nigeria. Environ. Monit. Assess. 2018, 190, 235. [CrossRef]

39. Okoye, C.O.B.; Ugwu, J.N. Impact of environmental cadmium, lead, copper and zinc on quality of goat meat in Ni-geria. Bull. Chem. Soc. Ethiop. 2010, 24, 133-138. [CrossRef]

40. Okolo, C.C.; Oyedotun, T.D.T.; Akamigbo, F.O.R. Open cast mining: Threat to water quality in rural community of Enyigba in south-eastern Nigeria. Appl. Water Sci. 2018, 8, 204. [CrossRef]

41. Adetunji, V.; Famakin, I.; Chen, J. Lead and cadmium levels in cattle muscle and edible tissues collected from a slaughter slab in Nigeria. Food Addit. Contam. Part B 2013, 7, 79-83. [CrossRef] [PubMed]

42. Bala, A.; Junaidu, A.U.; Salihu, M.D.; Agaie, B.M.; Saulawa, M.A.; Musawa, A.I.; Ahmad, K.H. Determination of Heavy Metal Residues in Slaughtered Camels at Sokoto and Gusau Modern Abattoirs, Nigeria. J. Health Pollut. 2018, 8, 181204. [CrossRef] [PubMed]

43. Chadi, A.S.; Abdulhameed, A. Assessment of heavy metals contents in goat and sheep organs from Ashaka ce-ments, Gombe State, Nigeria. J. Water Technol. Treat. Methods 2018, 1, 1-5. [CrossRef]

44. Enugu State Government. About Enugu State-Geographical Location/Demography. 2006. Available online: https://www. enugustate.gov.ng/index.php/elements-devices/ (accessed on 29 March 2021).

45. Nwanta, J.A.; Onunkwo, J.I.; Ezenduka, E.V.; Phil-Eze, P.O.; Egege, S.C. Abattoir operations and waste management in Nigeria: A review of challenges and prospects. Sokoto J. Vet. Sci. 2008, 7, 61-67.

46. Pace, J.E.; Wakeman, D.L. Determining the Age of Cattle by Their Teeth, University of Florida, IFAS Extension. 2003. Available online: http:/ / www.edis.ifas.ufl.edu (accessed on 11 April 2020).

47. Nwude, D.O.; Babayemi, J.O.; Abhulimen, I.O. Metal quantification in cattle: A case of cattle at slaughter at Ota Abattoir, Nigeria. J. Toxicol Environ. Health Sci. 2011, 3, 271-274.

48. United state Environmental Protection Agency (USEPA). Risk-Based Concentration Table. Available online: https://epa-prgs. ornl.gov/cgi-bin/chemicals/csl_search (accessed on 18 January 2021).

49. Food and Agriculture Organization; World Health Organization. Evaluation of Certain Food Additives and Contaminants (SeventyThird Report of the Joint FAO/WHO Expert Committee on Food Additives); WHO Technical Report Series 960 held in Geneva, Switzerland in 2011; World Health Organization: Geneva, Switzerland, 2011.

50. Naseri, K.; Salmani, F.; Zeinali, M.; Zeinali, T. Health risk assessment of $\mathrm{Cd}, \mathrm{Cr}, \mathrm{Cu}, \mathrm{Ni}$ and $\mathrm{Pb}$ in the muscle, liver and gizzard of hen's marketed in East of Iran. Toxicol. Rep. 2021, 8, 53-59. [CrossRef] [PubMed]

51. Khatri, N.; Tyagi, S. Influences of natural and anthropogenic factors on surface and groundwater quality in rural and urban areas. Front. Life Sci. 2015, 8, 23-39. [CrossRef]

52. Thompson, L.A.; Darwish, W.S. Environmental Chemical Contaminants in Food: Review of a Global Problem. J. Toxicol. 2019, 2019, 1-14. [CrossRef] [PubMed]

53. Semu, E.; Tindwa, H.; Singh, B.R. Heavy Metals and Organopesticides: Ecotoxicology, Health Effects and Mitigation Options with Emphasis on Sub-Saharan Africa. Toxicol. Curr. Res. 2019, 3, 1-14. [CrossRef]

54. Seyoum, Z.; Tadesse, T.; Addisu, A. Ectoparasites Prevalence in Small Ruminants in and around Sekela, Amhara Regional State, Northwest Ethiopia. J. Vet. Med. 2015, 2015, 1-6. [CrossRef] [PubMed]

55. Sobukola, O.P.; Adeniran, O.M.; Odedairo, A.A.; Kajihausa, O.E. Heavy metal levels of some fruits and leafy vegeta-bles from selected markets in Lagos, Nigeria. Afr J. Food Sci. 2010, 4, 389-393.

56. Ajah, K.C.; Ademiluyi, J.; Nnaji, C.C. Spatiality, seasonality and ecological risks of heavy metals in the vicinity of a degenerate municipal central dumpsite in Enugu, Nigeria. J. Environ. Health Sci. Eng. 2015, 13, 15. [CrossRef] [PubMed] 
57. Sun, R.; Chen, L. Assessment of Heavy Metal Pollution in Topsoil around Beijing Metropolis. PLoS ONE 2016, 11, e0155350. [CrossRef] [PubMed]

58. Kunal, K.S.; William, W.S. Role of lead in the central nervous system: Effect on electroencephlography, evoked po-tentials, electroretinography, and nerve conduction. Neurodiagn J. 2015, 55, 107-121.

59. Daneshparvar, M.; Mostafavi, S.-A.; Jeddi, M.Z.; Yunesian, M.; Mesdaghinia, A.; Mahvi, A.H.; Akhondzadeh, S. The Role of Lead Exposure on Attention-Deficit/ Hyperactivity Disorder in Children: A Systematic Review. Iran. J. Psychiatry 2016, 11, 1-14. [PubMed]

60. Lee, M.-J.; Chou, M.-C.; Chou, W.-J.; Huang, C.-W.; Kuo, H.-C.; Lee, S.-Y.; Wang, L.-J. Heavy Metals' Effect on Susceptibility to Attention-Deficit/Hyperactivity Disorder: Implication of Lead, Cadmium, and Antimony. Int. J. Environ. Res. Public Health 2018, 15, 1221. [CrossRef] [PubMed]

61. Vaziri, N.D. Mechanisms of lead-induced hypertension and cardiovascular disease. Am. J. Physiol. Circ. Physiol. 2008, 295, H454-H465. [CrossRef] [PubMed]

62. Abdullahi, M.S. Toxic effects of lead in humans: An overview. Glo Adv. Res. J. Environ. Sci. Technol. 2013, 2, 157-162.

63. Agency for Toxic Substances and Disease Registry. Lead Toxicity: What Are Possible Health Effects from Lead Exposure? 4770 Buford Hwy NE Atlanta, GA 0341. Available online: https:/ / www.atsdr.cdc.gov/csem/csem.asp?csem=34\&po=10 (accessed on 15 September 2020).

64. Martinez, V.D.; Vucic, E.A.; Becker-Santos, D.D.; Gil, L.; Lam, W.L. Arsenic Exposure and the Induction of Human Cancers J. Toxicol. 2011, 2011, 1-13. [CrossRef] [PubMed]

65. Chen, Q.Y.; Desmarais, T.; Costa, M. Metals and Mechanisms of Carcinogenesis. Annu. Rev. Pharmacol. Toxicol. 2019, 59, 537-554. [CrossRef] [PubMed]

66. Hirano, S. Biotransformation of arsenic and toxicological implication of arsenic metabolites. Arch. Toxicol. 2020, 94, 2587-2601. [CrossRef] [PubMed]

67. Hong, Y.-S.; Song, K.-H.; Chung, J.-Y. Health Effects of Chronic Arsenic Exposure. J. Prev. Med. Public Health 2014, 47, $245-252$. [CrossRef]

68. Singh, N.; Kumar, D.; Sahu, A.P. Arsenic in the environment: Effects on human health and possible prevention. J. Environ. Biol. 2007, 28, 359-365. [PubMed]

69. Zheng, Y.; Shen, Y.; Zhu, Z.; Hu, H. Associations between Cadmium Exposure and Taste and Smell Dysfunction: Results from the National Health and Nutrition Examination Survey (NHANES), 2011-2014. Int. J. Environ. Res. Public Health 2020, 17, 943. [CrossRef] [PubMed]

70. De La Fuente, H.; Portales-Pérez, D.; Baranda, L.; Díaz-Barriga, F.; Saavedra-Alanís, V.; Layseca, E.; González-Amaro, R. Effect of arsenic, cadmium and lead on the induction of apoptosis of normal human mononuclear cells. Clin. Exp. Immunol. 2002, 129, 69-77. [CrossRef] [PubMed]

71. Al-Ghafari, A.; Elmorsy, E.; Fikry, E.; Alrowaili, M.; Carter, W.G. The heavy metals lead and cadmium are cytotoxic to human bone osteoblasts via induction of redox stress. PLoS ONE 2019, 14, e225341. [CrossRef] [PubMed]

72. Hildebrand, J.; Thakar, S.; Watts, T.-L.; Banfield, L.; Thabane, L.; Macri, J.; Hill, S.; Samaan, M.C. The impact of environmental cadmium exposure on type 2 diabetes risk: A protocol for an overview of systematic reviews. Syst. Rev. 2019, 8, 1-7. [CrossRef] [PubMed]

73. Akinloye, O.; Ogunleye, K.; Oguntibeju, O.O. Cadmium, lead, arsenic and selenium levels in patients with type 2 diabetes mellitus. Afr. J. Biotechnol. 2010, 9, 5189-5195.

74. Luevano, J.; Damodaran, C. A Review of Molecular Events of Cadmium-Induced Carcinogenesis. J. Environ. Pathol. Toxicol. Oncol. 2014, 33, 183-194. [CrossRef]

75. Kulawik, P.; Dordevic, D.; Gambuś, F.; Szczurowska, K.; Zając, M. Heavy metal contamination, microbiological spoilage and biogenic amine content in sushi available on the Polish market. J. Sci. Food Agric. 2018, 98, 2809-2815. [CrossRef]

76. Antoine, J.M.; Fung, L.A.H.; Grant, C.N. Assessment of the potential health risks associated with the aluminium, arsenic, cadmium and lead content in selected fruits and vegetables grown in Jamaica. Toxicol. Rep. 2017, 4, 181-187. [CrossRef] [PubMed]

77. Ekhator, O.C.; Udowelle, N.A.; Igbiri, S.; Asomugha, R.N.; Igweze, Z.N.; Orisakwe, O.E. Safety Evaluation of Potential Toxic Metals Exposure from Street Foods Consumed in Mid-West Nigeria. J. Environ. Public Health 2017, 2017, 8458057. [CrossRef] [PubMed]

78. Wright, N.J.; Thacher, T.D.; Pfitzner, M.A.; Fischer, P.R.; Pettifor, J.M. Causes of lead toxicity in a Nigerian city. Arch. Dis. Child. 2005, 90, 262-266. [CrossRef] [PubMed]

79. Centers for Disease Control and Prevention. Lead Poisoning Investigation in Northern Nigeria. Available online: https: //www.cdc.gov/onehealth/in-action/lead-poisoning.html (accessed on 16 February 2021).

80. Dooyema, C.A.; Neri, A.; Lo, Y.-C.; Durant, J.; Dargan, P.I.; Swarthout, T.; Biya, O.; Gidado, S.O.; Haladu, S.; Sani-Gwarzo, N.; et al Outbreak of Fatal Childhood Lead Poisoning Related to Artisanal Gold Mining in Northwestern Nigeria, 2010. Environ. Health Perspect. 2012, 120, 601-607. [CrossRef] [PubMed]

81. Lo, Y.-C.; Dooyema, C.A.; Neri, A.; Durant, J.; Jefferies, T.; Medina-Marino, A.; De Ravello, L.; Thoroughman, D.; Davis, L.; Dankoli, R.S.; et al. Childhood Lead Poisoning Associated with Gold Ore Processing: A Village-Level Investigation-Zamfara State, Nigeria, October-November 2010. Environ. Health Perspect. 2012, 120, 1450-1455. [CrossRef] 
82. Ajumobi, O.O.; Tsofo, A.; Yango, M.; Aworh, M.K.; Anagbogu, I.N.; Mohammed, A.; Umar-Tsafe, N.; Mohammed, S.; Abdullahi, M.; Davis, L.; et al. High concentration of blood lead levels among young children in Bagega community, Zamfara-Nigeria and the potential risk factor. Pan Afr. Med. J. 2014, 18, 14. [CrossRef] [PubMed]

83. Getso, K.I.; Hadejia, I.S.; Sabitu, K.; Nguku, P.M.; Poggensee, G.; Aliyu, H.M.; Yalwa, H.; Sani-Gwarzo, N.; Oyemakinde, A. Prevalence and Determinants of Childhood Lead Poisoning in Zamfara State, Nigeria. J. Health Pollut. 2014, 4, 1-9. [CrossRef]

84. Ladele, A.A.; Joseph, K.; Omotesho, O.A.; Ijaiya, T.O. Sensory quality ratings, consumption pattern and preference for some selected meat types in Nigeria. Int. J. Food Sci. Nutr. 1996, 47, 141-145. [CrossRef] [PubMed] 